\title{
Social and Health Care of Children in Central Europe The Italian Hospital in Prague in the 17 th-18th Century
}

\author{
Petr Svobodný
}

\section{Introduction}

Particularly in the Romance lands of Europe (Italy, France and Spain), ${ }^{1}$ care of orphans and abandoned children was an important part of care of children from the Earlier Middle Ages. It is therefore not surprising that the first institution to take a major interest in the care of children in Prague (Bohemia - today in the Czech Republic) was founded by members of the Italian colony in what was then an imperial, but later only the provincial capital. At the beginning the Italian Congregation and its hospital provided lodging and aid for all, regardless of nationality, religion, age or sex. At the turn of the $17 \mathrm{th} / 18$ th century, as a result of fruitful competition with other traditional hospitals and newly founded specialised hospitals, the Italian Hospital started to focus primarily on care of children orphans and foundlings - and later also pregnant women and new mothers. ${ }^{2}$ The hospital was also distinctive for not having been set up by a religious order or other church organisation nor by the city authorities like other similar facilities, but by a special religious congregation of laymen, formed mainly (if not exclusively) for the purpose. In this context the Italian Congregation in Prague differed from all other religious congregations/brotherhoods in Bohemia. There is no other "hospital"

1 Enfance abandonée et société en Europe XIVe-XXe siecle, Collection de l'École Francaise de Rome 140 (Rome, 1991).

2 Petr Svobodný, "L’Ospedale italiano come struttura socio-sanitaria (1602-1789)", in Anna Bortolozzi, ed., La Congregazione italiana di Praga (Praga, 2003), pp. 26-38; J. Rigetti and J. C. Panich, Historische Nachricht sowohl von der Errichtung der Wellschen Congregation unter dem Titel Mariae Himmelfahrt als auch des dazu gehörigen Hospitals B. V. Mariae ad S. Carolum Borromeum (Prag, 1773); Joseph Anton Riegger, Materialien zur alten und neuen Statistik von Böhmen, VIII (Lipsia - Praga, 1788), pp. 153-186; O. Romanese, Riasunto storico sulla fondazione della Congregazione e sula erezione della Capella italiana (Praga, 1898). 
congregation to be found in Bohemia at that time, in contrast to the situation in other European countries. ${ }^{3}$

Medieval and early modern hospitals are rightly regarded as the forerunners of the modern hospital, even though originally the sick formed only a small proportion of their charges. The care provided for these charges was first and foremost care for their souls, and second provision for basic survival (food, clothing, a roof over their heads, ordinary care for the infirm); and only in last place were they provided with at least basic healthcare from the hands of the nursing attendants, wound-healers or even physicians. ${ }^{4}$ Although the history of the care provided by the Italian Congregation to needy persons dates from its establishment in 1573, we can only speak of a hospital from 1602, when the congregation purchased a house in the Lesser Town of Prague belonging to one of its members, Domenico de Bossi. For practically the entire 17th century the Italian Hospital did not differ much from the other Prague hospitals in its orientation: it took care of all people in need - the poor, the abandoned and the infirm - without regard to age or sex. The presence of sick people among its charges is indicated as early as 1608 in an imperial decree of that year. During the first half of the 18th century the Italian Hospital, as a specialised social-health institution, ranked in significance at the side of the two real Prague hospitals: the Hospital of the Brothers of Mercy in the Old Town of Prague at $\mathrm{Na}$ Františku (founded in 1620) and the Hospital of the Sisters of St. Elizabeth in the New Town of Prague at Na Slupi (founded in 1722). By this time it was already caring principally for children and pregnant women, and not only their social welfare needs, but their health needs as well. It thus became the direct predecessor of several modern health institutions (the provincial maternity hospital and foundling hospital), set up by the Enlightened reforms in the 1780s, as well one of the first clinical facilities of the Medical Faculty, and to a certain extent it was also the indirect predecessor of the later children's hospitals. ${ }^{5}$

3 Jiří Mikulec, Barokní náboženská bratrstva $v$ Cechách [Baroque Religious Congregations in Bohemia] (Praha, 2000), pp. 101-102.

4 Basic information on the history of Prague hospitals and health care in this period in Petr Svobodný, "L'Ospedale italiano come struttura socio-sanitaria (1602-1789)", in Anna Bortolozzi, ed., La Congregazione italiana di Praga (Praga, 2003), pp. 27-31; more detailed information about history of hospitals in Prague: Petr Svobodný and Ludmila Hlaváčková, Pražské špitály a nemocnice [Prague Infirmaries and Hospitals] (Praha, 1999). More general information in Petr Svobodný and Ludmila Hlaváčková, Dějiny medicíny v českých zemích [A History of Medicine in the Czech Lands] (Praha, 2004).

5 This paper is based on my original works cited in following footnotes. More detailed information about archival and other original sources ibidem. 


\section{The Institutional Development, Administration and Funding of the Italian Hospital}

The initial phase of the functioning of the hospital up to the end of the 17th century is in many respects (and especially from the point of view of care for charges) shrouded in obscurity because of a lack of sources. For the 18th century, especially its latter half when the hospital was at the height of its fame, the situation is much better. As an institution the Italian Hospital developed over the last third of the 16th century out of a religious and charitable initiative taken by the Italian colony that had gradually settled in Prague during the 15th and 16th centuries. The colony's Catholicism in a religiously divided Prague and its distinctive ethnic identity prompted first the organisation of special Italian masses in the Jesuit Church of St. Clement's, then in 1569 the building of a special Chapel of the Assumption of Our Lady for the community in the Clementinum College complex in the Old Town of Prague, and finally in 1573 the establishment of a congregation of the same name. ${ }^{6}$ As the motto of the congregation, Pro Deo et paupere shows, apart from religious obligations it set itself the goal of providing care of the poor and infirm. Initially it provided help for the needy in the private houses of individual members of the association. At the beginning of the century (1601) the number of needy persons in the house of the assistant of the congregation Domenico de Bossi in the Lesser Town of Prague alone had reached sixty, and so the following year de Bossi sold the house to the congregation. This meant that the congregation now had its own building, in which needy persons could be provided for on a long-term basis at an institutional level. The crucial official approval for the hospital institution was obtained in the form of an Imperial Decree from Rudolf II on the 24th of April 1608. By this decree the emperor at the request of leaders of the congregation freed the hospital from taxes and impositions, and granted it permission to purchase other properties necessary to expand the hospital and to accept gifts and legacies. One interesting aspect of the decree from the medical point of view is a prohibition on accepting infected persons in time of plague. The Lesser Town Corporation was named as the guarantee of the tax privileges. The text of the decree speaks only of the poor and sick as the recipients of the hospital's charity, and at no point specifically mentions children, who later predominated among the hospital's charges.

6 Anna Bartolozzi, "La Congregatione della Beata Virgine Maria Assunta in Cielo. Religione e carita nella migrazione degli italiani a Praga in eta moderna", in Anna Bortolozzi, ed., La Congregazione italiana di Praga (Praga, 2003), pp. 11-25. More detailed information on administrative and finances of the hospital in Petr Svobodný, "Vlašský špitál na Malé Straně a jeho místo v péči o matku a dítě josefinských reforem (1602-1789)" [“The Italian Hospital in Prague and its Place in the Care of Children”], Documenta Pragensia, 7 (1987), pp. 113-134; Petr Svobodný, "Das welsche Spital an der Kleinseite und seine Stellung in der Mutter- und Kindfürsorge vor den Josephinischen Reformen (1602-1789)", Historia Hospitalium, Heft 18 (1989-1992), pp. 79-91. 
Until its dissolution the legally and materially secured hospital was to remain housed in a majestic Baroque complex built at the very beginning of the 17th century. Its core was the house of the member of the congregation already mentioned, the architect de Bossi, in Vlašská [Italian] Street. Reconstruction of this house started even before the Battle of the White Mountain (1620), and the Hospital Church of Our Lady and St. Charles Borromeo was completed under the direction of the architects de Bossi and Pietro della Pasquino in 1617, but we lack documentary evidence on the construction of the hospital buildings. During the Thirty Years War (1618-1648) the hospital complex was twice plundered. The appearance of the church today was created by construction during 1643-44. The hospital acquired its basic square disposition around a beautiful courtyard with arcades in 1654 and was expanded in 1675. Just as in the Hospital of the Brothers of Mercy and the Sisters of St. Elizabeth, the internal arrangement of the Italian Hospital was highly practical for its time. It included separate rooms for women, men and children, and rooms for the management of the hospital and essential service areas. ${ }^{7}$

The latter half of the 17th century and first half of the 18th century brought no major legal or architectural changes; the emperor repeatedly confirmed the hospital's existing privileges and several small modifications were made to the buildings. Substantial change came only in the 1770 s as part of the reform programmes of Marie Theresa and her co-regent Joseph II. By an Imperial Decree of the 20th of January 1776 the New Town Foundling Hospital with the Mary Magdalena Maternity Hospital in Soukenická Street, which had been in operation since 1765 and financially supported by the Italian Congregation since 1774, was brought directly under the hospital itself. By another decree of the 29th of March 1777 the French Hospital of St. Louis in the New Town was also affiliated to the Italian Hospital for financial reasons. Shortly afterwards (1st of May 1777), the hospital purchased the Sporck House, adjacent to the hospital, in which a well equipped and properly run maternity hospital was then installed.

Radical official changes to the status of the Italian Hospital then came with the Josephinian Reforms to care for the sick and poor in the 1780s, and these eventually led to its closure. The rules of the Bohemian Provincial Government of 1784 for the reorganisation of institutes for the sick and paupers in Prague precisely defined categories of social-health institutions and their charges. Under these, the Italian Hospital, which was willing to submit to the supervision of the Prague Municipal Corporation and the supreme supervision of the Bohemian Provincial Government (gubernium), retained the character of an orphanage and foundling hospital with

7 More information on architecture of the hospital in Johana Kofroňová, "L'Ospedale italiano di Praga: genesi e storia dell'edificio", in Anna Bortolozzi, ed., La Congregazione italiana di Praga (Praga, 2003), pp. 43-56. 
maternity hospital. ${ }^{8}$ It was not to survive for long, however. On the basis of a court decree of the $31^{\text {st }}$ of December 1784 adult and child inmates were investigated for their property, health and moral status and then gradually moved to the appropriate newly established facilities (general hospital, lunatic asylum, poor hospital, poor house, maternity hospital, foundling hospital). Although most Prague older hospitals were dissolved in this year and their charges moved to the new institutions, the Italian Hospital actually continued to exist until the 17th of August 1789, when the last children and mothers were moved to the newly opened maternity hospital and foundling hospital of St. Apollinaire

The funding of the charitable activity of the hospital was at first covered by gifts and legacies, and later by the income from well-administered property. A statistical overview published by J. A. Riegger in 1788 offers a picture of the extent and composition of the hospital's property towards the end of its life, and one that indicates its gradual growth. ${ }^{9}$ The property was divided into the hospital's own immoveable property and endowment funds that were specially administered, with special separate accounts, by the management of the hospital. At the head of the clerks and other employees of the hospital there was an administrator who oversaw the economic running of the institute and submitted regular reports on it to the congregation authorities.

With just a few exceptions we have no precise documentary evidence of the number of attendants, male and female, who directly provided care for the charges and together with their superiors also conducted regular checks on the welfare of the children placed with wet-nurses and foster-parents. Nor do we have precise evidence on the number of wet-nurses. According to data from the end of the 1780 s more than ten attendants, mainly women, cared for charges directly in the hospital (one each for the men and women, 2 for the smaller children, 1 for smaller boys, 2 for older boys, 4 for girls, 1 for the sick). There was also originally one, and later two secular teachers, a hospital priest and his three assistants, a female needlework teacher and a military trainer. The health of the inmates was entrusted to external colleagues: a physician and a wound-healer (surgeon). As a rule these were Lesser Town official physicians and surgeons; we can name at least the professors of the Prague Medical Faculty Med. Dr. J. A. Cassinis (1645-1716) and Med. Dr. J. J. Bauer (1719-1802) or the surgeon Chir. Dr. J. Köller. The midwife Rosalie Sander assisted at births, and had an assistant who lived inside the maternity hospital.

8 Ludmila Hlaváčková, "200 Jahre seit der Gründung des Allgemeinen Krankenhauses in Prag”, Historia Hospitalium, Heft 18 (1989-1992), pp. 61-78.

9 Joseph Anton Riegger, Materialien zur alten und neuen Statistik von Böhmen, VIII (Lipsia - Praga, 1788), pp. 153-186. 


\section{The Italian Hospital as a Foundling Hospital and Orphanage}

Although the Italian Hospital did not admit children only, care of children became its main activity. We do not have solid evidence for the preponderance of child inmates over adults until the middle of the 18th century, but the proportion of the former rose strikingly especially in the latter half of the century. Care of adults remained as a relic of earlier even when the Italian Hospital had started to specialise in children and mothers. The other Pre-Josephinian hospitals also often took on the role of orphanages or foundling hospitals, but there were very few children among their charges.

When the Italian Congregation was formed in Prague at the end of the 16th century, Bohemian provincial and municipal laws refused illegitimate children property and other rights. Conditions in Italy, where special institutions for abandoned children had been founded early in the Middle Ages, were undoubtedly well known to the Prague Italians and this knowledge must certainly have been one of the reasons why it was their congregation, in particular, that should have made care for helpless children one of the purposes of its charitable work. According to the rules on the admission, care and upbringing of children in the Italian Hospital, published in 1788 by J. Riegger, the institution accepted legitimate and illegitimate children, newborns and older children, children born in Prague and "children bereft of all human help" of both sexes and without regard to religious faith. Despite the restrictions of rights suffered by illegitimate children in Bohemia in the 16th and 17 th centuries, the hospital children were not made serfs to any private authority but remained free persons. By a supreme imperial regulation the illegitimate children at the hospital obtained all the rights of legitimate children and were permitted to enter any profession, for example, and go on to higher education.

It is extremely hard to determine the numbers of children within the overall numbers of charges of the Italian Hospital on the basis of the scattered data in archival and printed sources. Nor is it always clear how many children lived directly in the hospital complex and how many with wet nurses, foster parents, in apprenticeships or in service. 90 charges are mentioned for the year 1723 but the proportion of children is not given (and this is also the case in the oldest data, for the year 1601), although in 1746 children evidently predominated among the 194 charges (the precise number of children is not stated). In 1757 the hospital was caring for 66 children, 25 men and 61 women. According to what is already more precise data for the 1770s and 1780s, the hospital was caring for 1000 persons on a regular basis, mainly children. The data for different years is hard to compare: sometimes it relates to a particular date but at other times gives the aggregate of the number of people cared for in a particular year. Sometimes it distinguishes between child and adult charges (in some years it even gives numbers of employees), and 
very rarely gives numbers of children according to age categories, or how long they had lived directly in the hospital or outside it. Of the overall number of roughly 700-900 children only around 1/6 lived directly in the hospital, while the others, at the cost of the hospital, were placed in the town and country with wet nurses, foster parents, in apprenticeships or in service. The ratio between girls and boys was essentially even. In 1773 the hospital was providing for 1,180 people including staff. In 1775, apart from an unknown number of adults, the hospital was maintaining 268 children younger than six years old, 159 children between 6 and 15, 30 boys in apprenticeships and 46 girls in service. In 1779, out of a total of 1131 charges cared for by 56 staff, there were 786 children younger than 15 years old and 139 boys and girls between 15 and 20 years of age. In June 1787, there were 221 foundling boys and 242 foundling girls, 294 orphan boys and 226 orphan girls younger than 20 years of age and a mere 39 adults. At the time when the hospital was dissolved it was caring for 786 children and young people (up to 20 years), 75 adult men and 124 adult women (including pregnant women and new mothers). ). ${ }^{10}$

Table 1. Numbers of Persons in the Wards of the Italian Hospital 1723-1789.

\begin{tabular}{|c|c|c|c|c|c|c|c|}
\hline \multicolumn{4}{|c|}{ Children } & \multicolumn{2}{|c|}{ Adults } & \multirow[b]{2}{*}{ Total } & \multirow[b]{2}{*}{ Note } \\
\hline Period & $0-6$ & $6-15$ & $15-20$ & $\mathrm{M}$ & $F$ & & \\
\hline 1723 & & & & & & 90 & \\
\hline 1746 & & & & & & 194 & Mainly Children \\
\hline 1757 & & 66 & & 15 & 61 & 152 & \\
\hline 1773 & & & & & & 1180 & $\begin{array}{l}\text { Incl. Staff and children at foster } \\
\text { parents }\end{array}$ \\
\hline 1775 & 268 & 159 & $76^{*}$ & & & & $\begin{array}{l}{ }^{*} 30 \text { boys in apprenticeship, } 46 \\
\text { girl in service }\end{array}$ \\
\hline 1776 Dec. 31 & & & & & & 793 & \\
\hline 1776 & & & & & & 996 & \\
\hline 1777 & & & & & & 1277 & \\
\hline 1778 Jan. 1 & & & & & & 889 & \\
\hline 1778 & & & & & & 1215 & \\
\hline 1779 & & 86 & 139 & & 62 & 1187 & Incl. Staff (56 persons) \\
\hline 1780 Jan. 1 & & & & & & 857 & \\
\hline 1783 & & & & & & 1005 & \\
\hline 1786 Dec. 31 & & & & & & 961 & \\
\hline 1787 June & & $983^{*}$ & & 17 & 22 & 1022 & $\begin{array}{l}\text { *Orphans: } 294 \text { boys, } 226 \text { girls; } \\
\text { foundlings } 221 \text { boys, } 242 \text { girls }\end{array}$ \\
\hline 1787 & & & & & & 1435 & \\
\hline 1788 Jan. 1 & & & & & & 950 & \\
\hline 1789 August & & 786 & & 75 & 124 & 985 & \\
\hline
\end{tabular}

Sources: Joseph Anton Riegger, Materialien zur alten und neuen Statistik von Böhmen, VIII (Lipsia - Praga, 1788), pp. 157, 169, 185. Ignaz Cornova, „Das Waiseninstitut der Italiener in Prag“, Hyllos (1819), p. 19. O. Romanese, Riasuntostorico sulla fondazione della Congregazione e sula erezione della Capella italiana (Praga, 1898), p. 24.

10 More detailed information on numbers and their sources in Petr Svobodný, Child Mortality in the Italian Hospital in Prague (1719-1789), Journal of Family History 19:2 (1994), pp. 117-129. 
Detailed reports have survived for the second half of the 18th century on the pattern of care specifically for children from their admission to the care of the hospital to their departure into independent life. The newly admitted children were first christened by the spiritual administrator of the hospital and then enrolled in the institution register by the administrator. Sucklings were placed with wet nurses in the city, who were paid a contribution of 30 kreutzers a week and were given linen and clothes for the children. After being weaned, the children stayed with foster parents, and were fully materially and financially secured by the hospital. Attendants and superiors from the hospital would regularly check on the responsible conduct of wet nurses and foster parents, and in cases of neglect, the children would be taken away from one foster parents and given to others. Once a year on the Sunday after the Feast of St. Mary Magdalene, all the children would be brought to the hospital by their wet nurses and foster parents to be inspected by the hospital superiors. When the children had reached the age when they could look after themselves (at 6-7 years old) they were taken back into the hospital, where they would be given all the necessary care.

In the hospital, the children would be accommodated in communal bedrooms. ${ }^{1}$ Each bed had a straw mattress and horsehair mattress, two blankets, a pillow and sheets. Various kinds of under-linen, clothes and shoes (including indoor slippers) in various different sizes are listed with accountant's precision in the inventory made when the hospital was dissolved in $1789 .{ }^{12}$ Meals were taken in a communal refectory, equipped with tables covered with tablecloths, and with simple benches; the children ate with complete sets of cutlery, not just spoons. The food was adjusted to the different ages and physical constitutions of the children, and for the sick on the basis of the recommendations of a doctor. Food was different for meat days, fasting days and festivals. On ordinary days lunch regularly included soup, and then usually beef and vegetables, while on Sundays and holy days there would be a 1/4 pint of beer as well. For supper there would only be soup.

Apart from caring for the bodily needs, the hospital also took care of the spiritual and moral development of the children. Every day, apart from attending two

11 Very interesting iconographical sources related to the history of the Italian Hospital in Prague describe hospital interiors equipped with beds with curtains. Compare drawings and pictures by Karel Škréta made for the hospital church in 1647, depicting St. Charles Borromeo visiting a plague hospital in Milano. More details on iconography in the Italian Hospital in Prague in Jan Royt, "La decorazione pittorica della capella della Vergine Maria e di S. Carlo Borromeo nell'Ospedale italiano", in Anna Bortolozzi, ed., La Congregazione italiana di Praga (Praga, 2003), 57-64; Tomáś Berger, "I dipinti recentemento scoperti sulla volta della cappella della Vergine Maria e di S. Carlo Borromeo, nell'Ospedale italiano: restauro e datazione", ibid, 65-70; Anna Bortolozzi, "San Carlo Borromeo, patrono dell'Ospedale italiano", ibid., 71-77.

12 Compare its edition in Petr Svobodný, "Inventár vlašského špitálu na Malé Straně z roku 1789" ["An Inventory of the Italian Hospital in Prague of 1789"], Documenta Pragensia, 8 (1988), 35-57. Original in the Archiv hlavního města Prahy [Prague Municipal Archives], G $16 / 141$. 
obligatory masses and several prayers in the hospital church, the children would study in their own two-class school, equipped with school benches, blackboards and pictorial teaching aids. The curriculum was composed of religion, reading, writing and arithmetic. In addition the girls would learn needlework, knitting, spinning and laundering, while the boys had preliminary military exercises. To discourage sloth and idleness there was a spinning room and knitting school, which apart from the educational effects had economic benefits for the hospital as well.

On reaching 14-15 the boys were sent into apprenticeships of their own choice. For the duration of their apprenticeship (5-6 years), the hospital would also then supply them with clothes and cover their teaching expenses. On completing their apprenticeships they would then get new clothes and money for their journeyman travels, and this would be the last support that they obtained before embarking on independent life. Their free status in the Italian Hospital meant that specially gifted boys could go on to higher studies. At the age of 14-15 girls would be placed in service in Prague or in the countryside, during which time they would be supported in the same way as the boys. Their last contribution from the hospital property was a dowry of 30 guldens. Every year a special foundation gave a dowry of 20 guldens to another four girls outside the hospital who had to show official proof of marriage.

In case of sickness the hospital not only provided special care for children with foster parents and in the hospital, which was regularly visited by a physician and surgeon, but also ensured health care for its charges in apprenticeships and in service. The sick were isolated in their own hospital room. In cases where a boy or girl suffered long-term effects of ill health and could not continue to earn a livelihood, they were provided for by the hospital for life. Even the last needs of its charges were organisationally and financially secured by the Italian hospital, since like most of the older hospitals it had its own cemetery.

Although the registers of births and deaths kept by the Italian Hospital for the years 1719-1789 have survived, ${ }^{13}$ they were kept in a peculiar way that makes them hard to compare with the data kept by ordinary parishes. Nonetheless, demographically analysed they allow us to gain a more precise picture, however relative, of the running of the hotel and especially its degree of success in caring for children. For newborns, sucklings and children up to six years old, the hospital was only a relative protection from the usual cruel fate of orphans and foundlings, since despite all the care provided these children died more often than their contemporaries in their own families. It was only in children of school age that the advantages of enforced life in the hospital, including regular meals and healthcare, could become apparent. Hospital children who survived to the age of 15-20 even

13 Archiv hlavního města Prahy [Prague Municipal Archives], Birth and Death Register 1719-1771, sig. N1 Z1, Birth and Death Register 1771-1789, sig. N3 Z2. 
had an incomparably greater chance of successfully entering adult life (school, apprenticeship, dowry etc.) than most of their contemporaries. ${ }^{14}$

\section{The Maternity Hospital at the Italian Hospital}

The Italian Hospital also differed from the other hospitals of its time by providing care for the pregnant and new mothers, although it took on this role relatively late. Its exceptionalism in this respect was underlined when it was chosen as the place for clinical teaching of obstetrics at the Prague Medical Faculty. On the 30th of June 1776, 177 children and eight "fallen" women were moved from the foundling hospital and maternity hospital of Mary Magdalena to the Italian Hospital. From that time on, therefore, a properly run maternity hospital existed at the Italian Hospital. Here poor women could find a refuge and expert help in case of emergency or extreme need (it was normal to give birth at home). Their - mainly unwanted - children would then usually became charges of the foundling hospital with better starting conditions than those that had been left on its doorstep. According to the proposals for the directive rules of $1785,{ }^{15}$ the place was envisaged as primarily a place where "fallen" women could give birth, and the service was free of charge for those who could produce a confirmation of poverty from a priest. These new mothers were then obliged to wet-nurse hospital sucklings without charge (a similar practice was to be prescribed at the new St. Apollinaire Hospital). Mothers with new-borns were placed in the former Sporck House adjacent to the original hospital building. The inventory of 1789 mentioned above provides a picture of the premises and equipment of the maternity hospital, which in rough outline suggests the way that it functioned. One of the rooms at that time served as a treatment room, in the next there were two special birth beds, one ordinary bed and a mangle, and in the third there was an ordinary birth bed, 20 beds for lying-in mothers separated by curtains, a tin basin, a child's bath and other small pieces of furniture.

Similar practices, and the midwife herself, Rosalie Sander, characterised the last years of the maternity hospital at the Italian Hospital and the first years of the new Land Maternity Hospital at St. Apollinaire. At St. Apollinaire the midwife was assisted by three attendants, while in the case of the Italian Hospital we have evidence of only one. A surgeon would assist in more difficult births.

According to the proposals of the directive rules, poor women giving birth free of charge also had to submit to demonstrations during the teaching of practical obstetrics to students of medicine and midwives. For the academic years 1784/85 and 1785/86 these obstetrical demonstrations were announced by a lector at the

14 More detailed information in Petr Svobodný, "Child Mortality in the Italian Hospital in Prague (1719-1789)", Journal of Family History 19:2 (1994), pp. 117-129.

15 National Archives in Prague, Bohemian Government - Publice 1784-1785, D III/49/100, 113, box nr. 965, the proposals for the directive rules, 1785 . 
Medical Faculty, Hynek Ruth (1731-1797). The demonstrations were advertised as twice weekly and designed for both medical and surgical studies. For the years 1786-1789 no practical teaching is recorded, or else the lecture lists are missing, and even for the years 1784 to 1786 we have no evidence of whether the clinical teaching actually took place.

The transfer of the last children and mothers from the dissolved Italian Hospital to the new foundling hospital and maternity hospital at St. Apollinaire thus started a new phase in the development of care for abandoned children and pregnant women and for the clinical teaching of obstetrics in Prague. The activity of the Italian Hospital in the last two decades of its existence was an important organisational and material precondition for this new phase.

The short period of existence of a maternity hospital at the Italian Hospital in Prague is actually an important chapter in the history of obstetrics and gynaecology in the Enlightenment era in the Bohemian lands. The beginning of the process of professionalisation and masculinisation of the field under the supervision of authority (here the Prague Medical Faculty) is, however, only one element of the problem in the context of research on gender identity and bio-power. ${ }^{16}$

\section{The Italian Hospital and Anatomical Autopsies at the Medical Faculty}

Even before it obtained a maternity hospital, however, the hospital had been serving university medical teaching needs. ${ }^{17}$ From the 1760s (like the Hospital of the Merciful Brethren) it was obliged to supply the Medical Faculty with the bodies of dead charges for demonstration autopsies. Prague university physicians and students originally conducted their explorations of human anatomy actually inside the Hospital of the Brothers of Mercy Na Františku. The first recorded autopsy since 1600 (the famous anatomy class of Johannes Jessenius) was conducted here in 1685 by Professor S. K. Zeidler (1620-1689). Later autopsies were moved to the medical lecture hall in the Carolinum College, where in 1723 the anatomy theatre was reconstructed at the instigation of Professor J. I. Mayer (1693-1757). The supply of bodies from the Hospital of the Brothers of Mercy was erratic and also limited to the bodies of adult men. Practical anatomy teaching was therefore greatly improved by the personal initiative of Professor J. T. Klinkosch (1734-1778), who

16 Compare Daniela Tinková, "V zájmu 'přirozenosti věcí'. Genderové identity, 'biomoc' a osvícenská věda" [In the Name of ,Nature of Things': Gender Identities, ,Bio-power' and Enlightened Science], in Práce z dèjin védy, VI (Praha, 2003), 571-615; Daniela Tinková, Déicide, suicide, infanticide. Crime, péche, folie; la transformation de la conception du "crime" et le process de decriminalization a l'epoque des Lumieres en France et dans la monarchie des Habsbourg; étude compare, Dissertation, EHESS (Paris, 2002).

17 On the Medical Faculty in Prague: Ludmila Hlaváčková and Petr Svobodný, "The Medical Faculty”, in Ivana Čornejová, Michal Svatoš and Petr Svobodný, eds., A History of Charles University I, 1348-1802 (Prague, 2001), pp. 405-438. 
requested permission to dissect children's bodies, to be supplied by what was at the time the only hospital specialising in care of children. In May 1763 the Medical Faculty was informed of the decision of the Royal University Commission, to the effect that the Italian Hospital as well as the Hospital of the Merciful Brethren would now be obliged to supply dead bodies for dissection.

The first documented removal of a child's corpse from the Italian Hospital to the Carolinum for dissection is recorded in the death register as early as the 10th of June of the same year, and from October the practice became routine. The bodies of the dead children would be supplied for dissections in the winter and spring months (November to April), which naturally corresponded to the term of lectures and demonstrations announced by Klinkosch in the winter semester. In the registers this practice is precisely documented up to 1771 , when the volume of the older register ends. ${ }^{18}$ It was undoubtedly continued in the following period, but in the new register there was no special section to record it. One body a week was best for teaching purposes, but of course the number of children's bodies supplied by the hospital to the Carolinum dissection room depended among other things on the number of deaths in the hospital. Nonetheless, from 1763 the conveyance of "anatomical material" was much more regular than at any time before and in the 1770 s allowed for the drawing up of a precise advance timetable for autopsy demonstrations. Overall roughly every second child to die at the hospital was taken for dissection, the bodies of infants of up to one year being the majority. Prof. Klinkosch invited attendance at his anatomical demonstrations not only with regular notices for students, but also in the titles of some of his publications, for example of 1764 and 1767. The most valuable of his monographs is a publication on the anatomy of the stomach and localisation of hernia of 1764 (with an invitation to demonstrations in the following year), which in addition to information taken from the extensive cited literature is also based on his own rich experience acquired during dissections. ${ }^{19}$

The anatomical dissections of children's bodies brought from the Italian Hospital therefore contributed to the teaching of new doctors and to the scientific work of the professor himself. The findings not only enriched anatomy, but contributed to the understanding of the specific features of children's health and disease that were later to become the subject of a separate field - paediatrics.

18 Compare the footnote 13.

19 More detailes in Petr Svobodný, "Vlašský špitál a anatomické pitvy na pražské lékařské fakultě v 60. a 70. letech 18. stoletî" [The Italian Hospital in Prague and Anatomical Dissections at the Medical Faculty in 1760s-1770s], Casopis lékařu českých 131 (1992), pp. 152153. 


\section{Conclusions}

In 1773 the Italian Congregation in Prague and its hospital celebrated the 200th anniversary of its founding. ${ }^{20}$ The many-sided vocation of the hospital was illustrated by allegorical pictures painted in the Italian Chapel (the main shrine of the Prague Italians in the Clementinum College in the Old Town), and by the inscription:

Quos spernit genitrix, hos per sua munera servat,

enutrit miseros, quodque necesse docet,

Respirantque senes, aegris medicina paratur,

Postremo tumulu moriuntur habent.

("Of its office it makes provision for those rejected by their mother, supports the poor, teaches what is necessary, the old find relief here, and in the end the dying find a grave here.") Although the traditional, essentially still medieval hospital was making efforts by the time of the anniversary celebrations and also later in the time of the revolutionary Enlightenment reforms of social welfare and healthcare to make modernising reforms, its already anachronistic universality and undoubtedly also its wealth, which was to become an important part of the newly established hospital fund, ultimately proved its undoing. It was dissolved as a charitable institution in 1789 by Joseph II, but many of the principles of its care, some of its charges (mothers and foundlings) and some members of its staff (the midwife) moved to the newly founded health institutes in the New Town (maternity hospital, foundling hospital). ${ }^{21}$

The history of the Italian Hospital in Prague from the end of the 16th to the end of the 18th century is a notable example of the formalisation, professionalisation and medicalisation of care for children: from the provision of a refuge for the most helpless members of society (abandoned newborns and orphans) who were completely bereft of the protection of the family, to progressively organisationally and professionally improving care offered by a lay religious congregation, to the ever more stringent supervision and finally the complete transfer of the social-health institution created in this way (a foundling hospital and maternity hospital) into a sphere entirely controlled by the authorities of the "State" (Bohemian provincial health institutions) and the "Academy" (the Medical Faculty in Prague).

20 Petr Svobodný, "I festeggiamenti per il giubileo della Congregazione e dell'Ospedale degli italiani nel 1773”, in Anna Bortolozzi, ed., La Congregazione italiana di Praga (Praga, 2003), pp. 89-92.

21 Franz A. Stelzig, Versuch einer medizinischen Topographie von Prag, II (Prag, 1824), p. 289 ff.; Julius V. Krombholz, Topographisches Taschenbuch von Prag (Prag, 1837), 454 ff. 
The "birth of the clinic" 22 in the Italian Hospital in Prague in the last quarter century of its existence sets the development of this particular institution, unusual in the Bohemian environment, firmly within the wider (Western) European context: "The mechanisms of power, which are said to have pervaded Western society since the end of the 18th century, are used as a method of explaining the emergence of various facets of modern medical practice, particularly the hospital, post-mortem, and clinical examination." ${ }^{23}$

Petr Svobodny, Doc. PhD, is Research Worker at the Institute for the History of Charles University and CU Archives, Charles University, Prague, Czech Republic. E-mail address: petr.svobodny@ruk.cuni.cz.

\section{Acknowledgement}

The study was supported by the Research Program "The Czech Lands in the Middle of Europe: Past and Present” (MSM 21620829).

22 Michel Foucault, The Birth of the Clinic. An Archaeology of Medical Perception (New York, 1975).

23 W. F. Bynum and Roy Porter, eds., Companion Encyclopedia of the History of Medicine (London: New York 2001), Vol. 2, p. 1658. 